\title{
Unravelling the evolution of regional-scale shear zones with the aid of microstructures and textural analysis: an example from the central Himalaya
}

\author{
Laura Nania
}

Dipartimento di Scienze della Terra, Università di Firenze, Italy.

Corresponding author e-mail: laura.nania@unifi.it

Document type: Short note.

Manuscript received 25 March 2021; accepted 25 June 2021; published online 1 July 2021; editorial responsibility and handling by G. Vignaroli.

\section{ABSTRACT}

Microstructure and texture data on the Main Central Thrust zone $(\mathrm{MCTz})$ in central Himalaya, on two nearly N-S oriented valleys in the Manaslu range (Western Nepal), are provided. Kinematic indicators at the meso and microscale support a south-directed flow. From south to north, greenschist facies paragneiss in the garnet-zone pass to amphibolite facies rocks in the kyanite-zone, suggesting an up-section metamorphic temperature increase. Combining microstructures and data from two different texture analysers (X-ray Texture goniometry and crystal-fabric microanalyzer) allowed to link the temperature path (from $460^{\circ} \mathrm{C}$ to $600^{\circ} \mathrm{C}$ up-section) and kinematic vorticity estimates. The "orientation of oblique grain shape fabrics" method was applied, pointing out a general shear flow (40-56\% of pure shear) at the MCTz top. Results are in line with a "decelerating strain-path" model, as relatively high simple shear components are recorded at deeper structural levels. This work highlights that the combination of $\mathrm{X}$-ray texture goniometry and crystal-fabric microanalyzer techniques is a good strategy to ensure quartz full-fabric.

KEYWORDS: Shear zones, quartz and dolomite fabric, kinematic vorticity, deformation temperatures, Himalaya.

\section{INTRODUCTION}

The study of regional scale shear zones is fundamental to infer the role of such structures in the deformation behaviour of the lithosphere, in different tectonic settings (e.g. Law et al., 2013; Fossen, 2016). Several modern techniques, needed for textural and microstructural characterization of naturally deformed rocks, have been applied to the study of regional scale shear zones in collisional belts, cropping out in the Himalaya along numerous structural transects.

This contribution focuses on the Main Central Thrust zone (MCTz) cropping out in the Marsyandi and the Budhi Gankadi valleys (Western Nepal). The MCTz is one of the most impressive and studied thrust, cropping out for over $2400 \mathrm{~km}$ along the Himalaya (Fig. 1a). Within few kilometres of vertical thickness, it accommodated 55-260 $\mathrm{km}$ of shortening during the Miocene (Parsons et al., 2020 with references). The MCTz involved the low-to-medium grade metamorphic rocks of the Lesser Himalayan Sequence (LHS), in the footwall, and the lower part of the medium-to-high-grade metamorphic rocks of the Greater
Himalayan Sequence $\left(\mathrm{GHS}_{\mathrm{L}}\right.$ ), in the hanging wall (Fig. 1a). Particularly, the MCTz played an important role for the exhumation of the metamorphic core of the belt (the GHS) from mid-crustal levels (Hodges et al., 1996; Searle et al., 2008; Law et al., 2013).

In the last decades, the understanding of the $\mathrm{MCTz}$ evolution became fundamental for the modelling of the tectonic exhumation mechanisms active in collisional orogens. However, given its impressive extension, thickness, and a lateral variability of the structure, defining the MCTz tectono-metamorphic evolution is a difficult task (Searle et al., 2008). It is not unambiguously defined if the MCTz sheared both the LHS and GHS or represents just a tectonic boundary between them (Godin et al., 2021 with references). Moreover, a clear break between the LHS and the $\mathrm{GHS}_{\mathrm{L}}$ is very rare along the belt, and this feature makes even more difficult to define, for example, the GHS and the location of the shear zone (Searle et al., 2008; Godin et al., 2021).

In NW India, the MCTz is defined by a composite structure, with an upper reverse shear zone (Vaikrita Thrust), and a southward-located, more external section at few kilometres of distance (Munsiari Thrust, e.g. Searle et al., 2008; Iaccarino et al., 2020; Montemagni et al., 2020 with references). Combining geochronological and kinematic investigations, Montemagni et al. (2020) proposed that the MCTz, in NW India, migrated from deeper to shallower levels, with a southward rejuvenation and a decelerating-strain path, from the Vaikrita Thrust to the Munsiari Thrust. Verifying this path through kinematic and temperature constrains in other areas of the Himalaya, expanding the database, may prove to be a useful strategy for future understanding of the MCTz.

The Manaslu area, in Western Nepal, is a key area for studying the MCTz. Several N-S striking valleys (e.g., from west to east, the Marsyandi and the Budhi Gankadi valleys) offer natural cross-sections of the belt (Fig. 1b). A sharp discontinuity between kyanite-zone gneisses (MP/MT) over amphibolite facies rocks (MP/HT), or Chomrong Thrust (Colchen et al., 1986), is documented from Bahundanda (Marsyandi Valley) to Tatopani (Budhi Gandaki valley) (Fig. 1b). After Hodges et al. (1996), the 
(a)

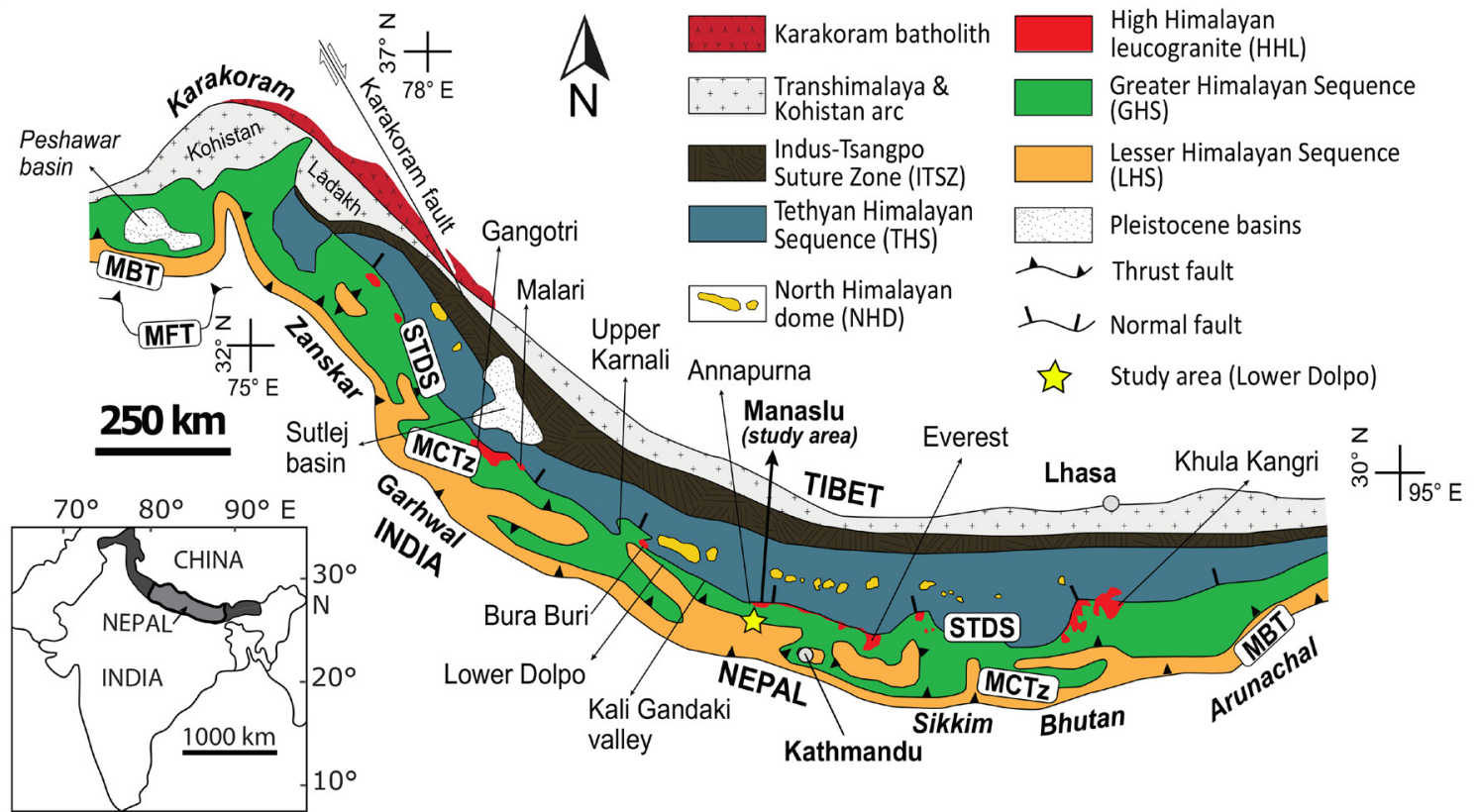

(b)

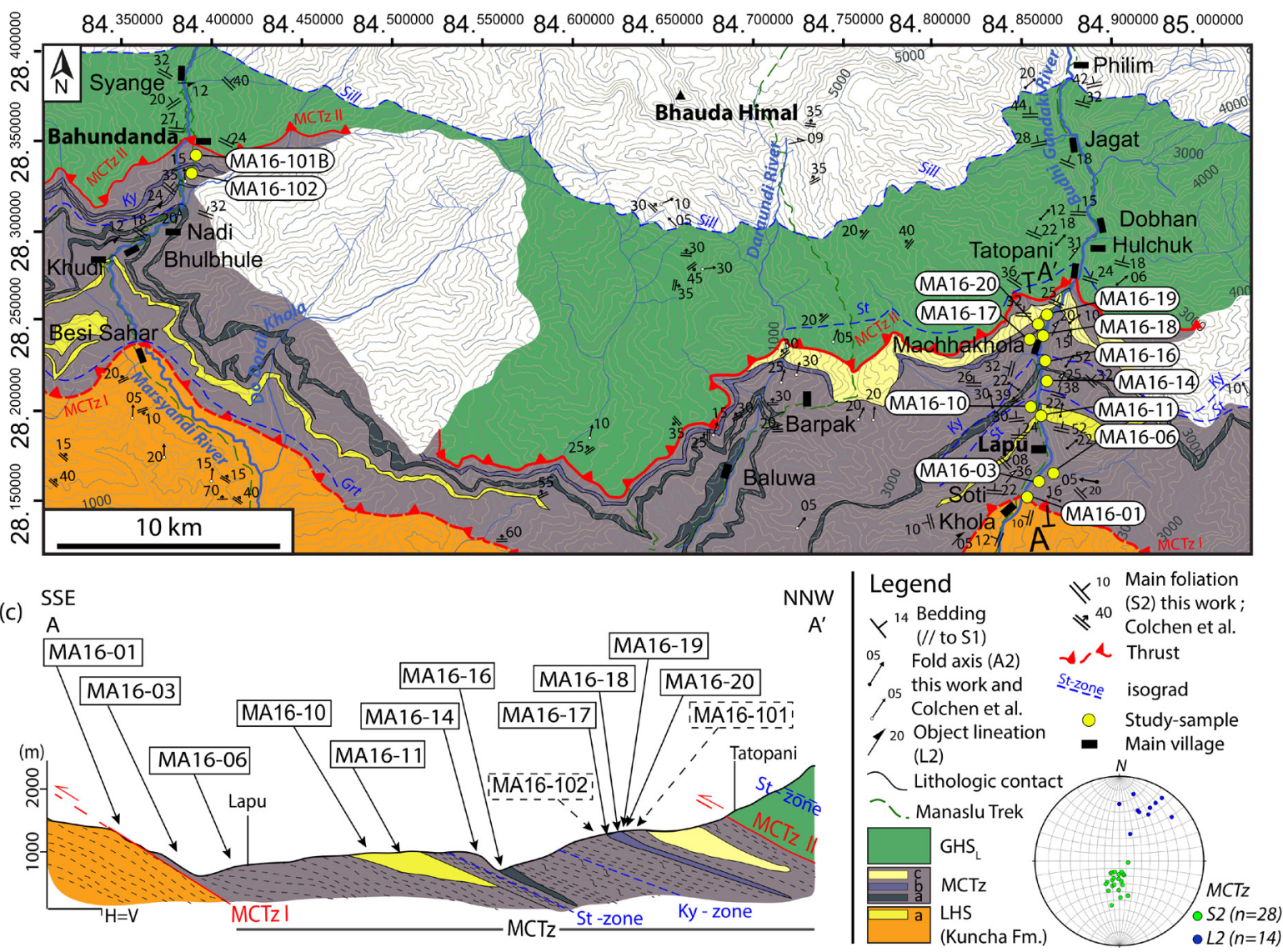

Fig. 1 - (a) Geological map of the Himalava (after Carosi et al., 2018). The study area, southward the Manaslu Massif, is highlighted. (b) Geological sketch map of the lower Masyandi and Budhi Gandaki valleys (study area) in Wester Nepal. Foliation (S2) and lineation (L2) are reported on the basis of the Colchen et al. (1986) geological map and the two field expeditions (2016 and 2017, see text for further details). S2 and L2 taken during the 2016 and 2017 expeditions are reported in the equal-angle lower hemisphere stereographic projection. (c) Geological cross section of A-A' trace (fig. 1b), where the studied samples are projected (same horizontal and vertical scales, as reported by $\mathrm{H}=\mathrm{V}$ ). Samples MA16-101 and MA16-102 are projected from the Marsyandi valley toward the west. Within the LHS, the a-horizon corresponds to the Ghandrung quartzite; whereas within the MCTz, the a-horizon corresponds to lower dolomitic marble, b-horizon to the upper dolomitic marble, and the c-horizon to the upper quartzites of Colchen et al. (1986). Abbreviations: Grt, garnet; Ky, kyanite; Sill, sillimanite; St, staurolite. 
Chomrong Thrust corresponds to the upper limit of the MCTz, or MCTz II (Fig. 1b, c), while the base of the shear zone (MCTz I) is documented few kilometres below. In this contribution, a microstructural and textural investigation of the MCTz, through different techniques, allowed us to estimate deformation temperatures and kinematic of the shear zone. Particularly for texture analyses, X-ray texture goniometry was coupled with analyses through the crystalfabric microanalyzer to ensure, with good accuracy, the quartz full-fabric of samples (e.g. Fazio et al., 2017).

\section{MATERIALS \& METHODS}

Microstructural analysis was performed on twenty oriented samples from Marsyandi and Budhi Gandaki valleys (Tab. 1), around the Manaslu area. Samples collected from bottom to top of MCTz profile were cut parallel to the object lineation and perpendicular to the main foliation (XZ plane of the finite strain ellipsoid). When dolomite grain-shape oblique foliations were recognized (e.g. Fig. 2b, c), the sectional kinematic vorticity number,

TABLE 1

Summary for the MCTz selected samples, referred to their unit and formation (see Fig. 1b for sample location). Samples are listed from bottom to top. Mineral assemblage, main features and related type of analysis are provided. Abbreviations: Ap, apatite; Bt, biotite; Cal, calcite; Chl, chlorite; Cpx, clinopyroxene; Dol, dolomite; Feld, feldspar; Grt, garnet; Kfs, K-feldspar; Mc, microcline; Mnz, monazite; Pl, plagioclase; Qtz, quartz; Wm, white mica; Rt, rutile; Tur, tourmaline; Zr, zircon; GBM, grain boundary migration; SGR, subgrain rotation recrystallization; Sb, oblique foliation; SPO, shape preferred orientation. The number associated with the analysis column corresponds to the type of analysis carried out on the sample, as: 1, microstructural analysis; 2, texture analysis through the X-ray Texture Goniometer; 3 , texture analysis through the crystal-fabric microanalyzer; 4 , kinematic vorticity.

\begin{tabular}{|c|c|c|c|c|c|}
\hline Sample & Unit & Mineral Assemblage & Lithotype & Fabric and deformation m. & Analysis \\
\hline MA16-01 & $\begin{array}{l}\text { LHS (MCTZ) } \\
\text { (Kuncha Fm.) }\end{array}$ & $\mathrm{Qtz}+\mathrm{Pl} / \mathrm{Kfs}+\mathrm{Bt}+\mathrm{Wm}+\mathrm{Chl}+\mathrm{Grt}+\mathrm{Tur}$ & $\begin{array}{l}\text { Grt+Tur } \\
\text { paragneiss }\end{array}$ & $\begin{array}{l}\text { S-C fabric top-to-S; } \\
\text { QTZ: SGR/GBM }\end{array}$ & 1,2 \\
\hline MA16-02 & $\begin{array}{l}\text { LHS (MCTZ) } \\
\text { (Kuncha Fm.) }\end{array}$ & $\mathrm{Qtz}+\mathrm{Pl}+\mathrm{Kfs}+\mathrm{Wm}+\mathrm{Bt}+\mathrm{Chl}+\mathrm{Grt}+\mathrm{Tur}$ & $\begin{array}{l}\text { Grt+Tur } \\
\text { paragneiss }\end{array}$ & $\begin{array}{l}\text { S2+S1; asymmetric structures } \\
\text { top-to-S; QTZ: SGR/GBM }\end{array}$ & 1 \\
\hline MA16-03 & $\begin{array}{l}\text { LHS (MCTZ) } \\
\text { (Kuncha Fm.) }\end{array}$ & $\begin{array}{l}\mathrm{Qtz}+\mathrm{Pl}+\mathrm{Kfs}+\mathrm{Wm}+ \\
\mathrm{Grt}+\mathrm{Tur}+\mathrm{Mnz}\end{array}$ & $\begin{array}{l}\text { Grt+Tur } \\
\text { paragneiss }\end{array}$ & $\begin{array}{l}\text { S-C fabric top-to-S; } \\
\text { QTZ: SGR/GBM }\end{array}$ & $1,2,3$ \\
\hline MA16-04 & $\begin{array}{l}\text { LHS (MCTZ) } \\
\text { (Kuncha Fm.) }\end{array}$ & $\mathrm{Qtz}+\mathrm{Pl} / \mathrm{Kfs}+\mathrm{Wm}+\mathrm{Bt}+\mathrm{Chl}+\mathrm{Tur}+\mathrm{Mnz}+\mathrm{Ap}$ & $\begin{array}{l}\text { Grt+Tur } \\
\text { paragneiss }\end{array}$ & $\begin{array}{l}\text { C-C'-S fabric top-to-S; } \\
\text { QTZ: SGR }\end{array}$ & 1 \\
\hline MA16-05 & $\begin{array}{l}\text { LHS (MCTZ) } \\
\text { (Kuncha Fm.) }\end{array}$ & $\begin{array}{l}\mathrm{Qtz}+\mathrm{Wm}+\mathrm{Bt}+\mathrm{Chl}+ \\
\text { Tur }+\mathrm{Zrn}+\mathrm{Ap}\end{array}$ & $\begin{array}{l}\text { Qtz-bearing } \\
\text { micaschist }\end{array}$ & $\mathrm{S} 2+\mathrm{S} 1$ foliations & 1 \\
\hline MA16-06 & $\begin{array}{l}\text { LHS (MCTZ) } \\
\text { (Kuncha Fm.) }\end{array}$ & $\begin{array}{l}\mathrm{Qtz}+\mathrm{Wm}+\mathrm{Bt}+\mathrm{Chl}+ \\
\mathrm{Zrn}+\mathrm{Ap}+\mathrm{Mnz}\end{array}$ & $\begin{array}{l}\text { Qtz-bearing } \\
\text { paragneiss }\end{array}$ & $\begin{array}{l}\text { S-C fabric top-to-SW; } \\
\text { QTZ: SGR/GBM }\end{array}$ & $1,2,3$ \\
\hline MA16-09 & LHS (MCTZ) & $\mathrm{Qtz}+\mathrm{Kfs}+\mathrm{Grt}+\mathrm{Wm}+\mathrm{Bt}+\mathrm{Tur}+\mathrm{Chl}$ & $\begin{array}{l}\text { Grt+Tur } \\
\text { micaschist }\end{array}$ & $\begin{array}{l}\text { S2+S1; C-C'-S fabric top-to-S; } \\
\text { QTZ: } \text { GBM }_{\text {I }}\end{array}$ & 1 \\
\hline MA16-10 & $\begin{array}{l}\text { LHS (MCTZ) } \\
\text { (massive quartzites) }\end{array}$ & $\mathrm{Qtz}+\mathrm{Kfs}+\mathrm{Pl}+\mathrm{Bt}+\mathrm{Wm}+\mathrm{Tur}+\mathrm{Ap}$ & Quartzite & $\begin{array}{l}\text { S-C fabric top-to-S; } \\
\text { QTZ: } \mathrm{GBM}_{\mathrm{I}} \text {; feld: plastic }\end{array}$ & 1,3 \\
\hline MA16-11 & $\begin{array}{l}\text { LHS (MCTZ) } \\
\text { (massive quartzites) }\end{array}$ & $\begin{array}{l}\text { Qtz+Kfs+Wm+Zr+ } \\
\text { Ap+Tur+Mnz }\end{array}$ & Quartzite & $\begin{array}{l}\text { S2+ asymmetric structures; } \\
\text { Qtz: GBM }\end{array}$ & $1,2,3$ \\
\hline MA16-14 & LHS (MCTz) & $\mathrm{Qtz}+\mathrm{Pl}+\mathrm{Kfs}+\mathrm{Wm}+\mathrm{Bt}+\mathrm{Mnz}$ & $\begin{array}{l}\text { Qtz-bearing } \\
\text { paragneiss }\end{array}$ & $\begin{array}{l}\text { S-C fabric top-to-SE; } \\
\text { QTZ: } \mathrm{GBM}_{\mathrm{r}} \text {; feld: plastic }\end{array}$ & $1,2,3$ \\
\hline MA16-15 & LHS (MCTz) & $\mathrm{Dol}+\mathrm{Qtz}+\mathrm{Wm}+\mathrm{Cpx}$ & $\begin{array}{l}\text { Dolomitic } \\
\text { marbles }\end{array}$ & S2: SPO (Dol); Dol: GBM & 1 \\
\hline MA16-16 & LHS (MCTz) & $\begin{array}{l}\mathrm{Dol}+\mathrm{Qtz}+\mathrm{Wm}+\mathrm{Bt}+ \\
\text { Tur+Mnz }\end{array}$ & $\begin{array}{l}\text { Dolomitic } \\
\text { marbles }\end{array}$ & Quartz in dolomite matrix & 1,2 \\
\hline MA16-17 & LHS (MCTz) & $\begin{array}{l}\mathrm{Dol}+\mathrm{Qtz}+\mathrm{Kfs}+\mathrm{Bt}+ \\
\mathrm{Wm}+\mathrm{Tur}\end{array}$ & $\begin{array}{l}\text { Dolomitic } \\
\text { marbles }\end{array}$ & S2+Sb: SPO (Dol); Dol: GBM & $1,2,4$ \\
\hline MA16-18 & LHS (MCTz) & $\begin{array}{l}\text { Qtz+Dol+Kfs+Bt+ } \\
\text { Wm+Tur }\end{array}$ & $\begin{array}{l}\text { Dolomitic } \\
\text { marbles }\end{array}$ & Quartz in dolomite matrix & 1,2 \\
\hline MA16-102 & LHS (MCTz) & $\mathrm{Qtz}+\mathrm{Pl}+\mathrm{Kfs}+\mathrm{Bt}+\mathrm{Wm}+\mathrm{Tur}+\mathrm{Mnz}+\mathrm{Ap}$ & $\begin{array}{l}\text { Tur-rich } \\
\text { quartzite }\end{array}$ & $\begin{array}{l}\text { S-C fabric top-to-S; } \\
\text { QTZ: } \mathrm{GBM}_{\mathrm{I}}+\text { annealing }\end{array}$ & $1,2,3$ \\
\hline MA16-19 & LHS (MCTz) & $\mathrm{Dol}+\mathrm{Qtz}+\mathrm{Kfs}+\mathrm{Bt}$ & $\begin{array}{l}\text { Dolomitic } \\
\text { marbles }\end{array}$ & S2+Sb: SPO (Dol); Dol: GBM & $1,2,4$ \\
\hline MA16-101 & LHS (MCTz) & $\mathrm{Qtz}+\mathrm{Pl}+\mathrm{Kfs}+\mathrm{Bt}+\mathrm{Wm}+\mathrm{Grt}+\mathrm{Mn}+\mathrm{Ap}+\mathrm{Tur}$ & $\begin{array}{l}\text { Grt- Tur- rich } \\
\text { quartzite }\end{array}$ & $\begin{array}{l}\text { S-C fabric top-to-S; } \\
\text { QTZ: GBM } \text {; feld: plastic }\end{array}$ & 1,3 \\
\hline MA16-20 & LHS (MCTz) & $\begin{array}{l}\mathrm{Dol}+\mathrm{Qtz}+\mathrm{Kfs}+\mathrm{Bt}+ \\
\mathrm{Wm}\end{array}$ & Marble & S2: SPO (Dol+Cal); Dol: GBM & 1,2 \\
\hline
\end{tabular}




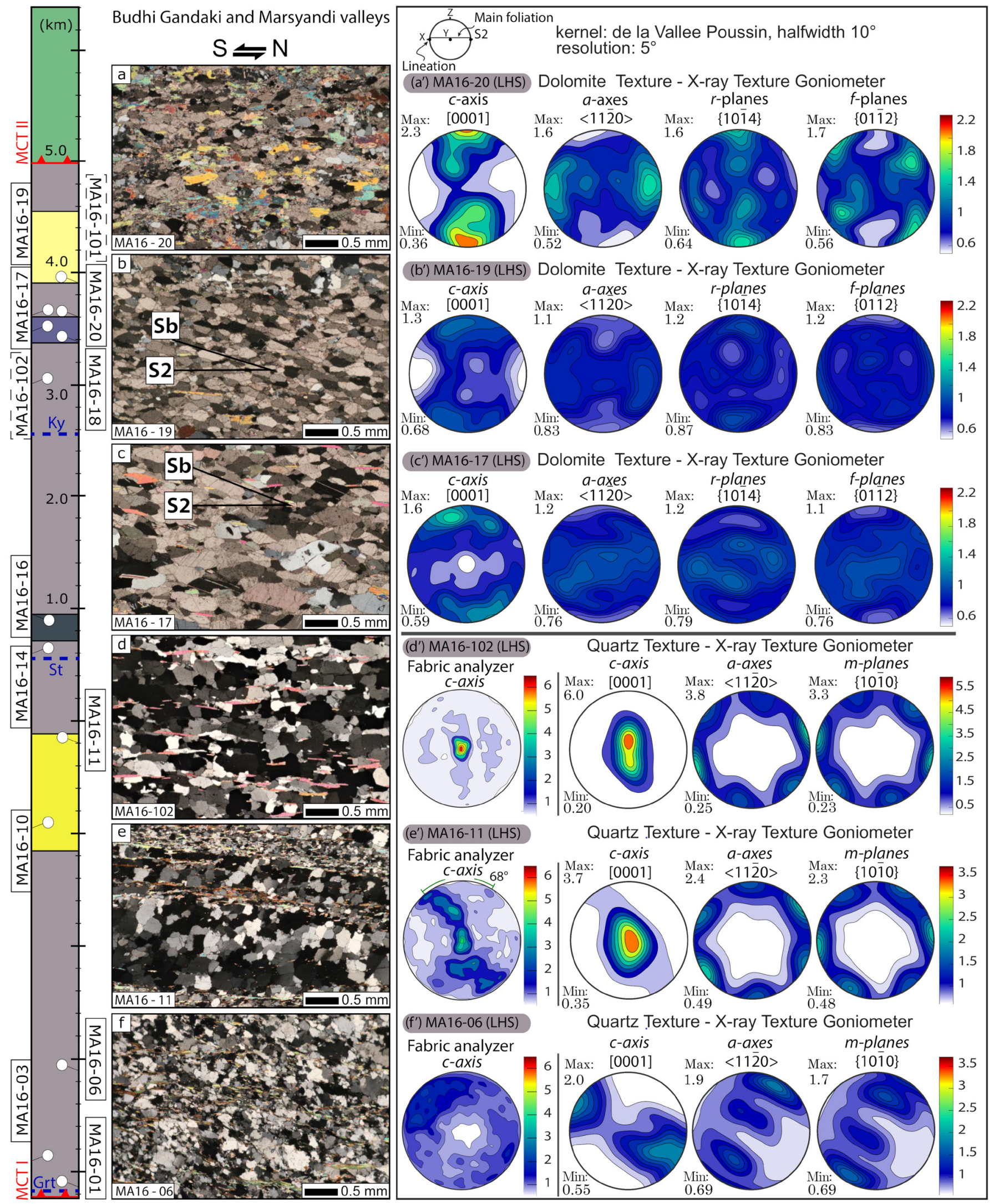

Fig. 2 - (a-f) Optical micrographs of key samples selected along the MCTz in the lower Masyandi and Budhi Gandaki valleys (see table 1). Location of selected samples on the structural section is displayed by white dots. The scale on the structural section corresponds to vertical thickness in kilometres. (a'-f') dolomite and quartz pole figures (equal area projection, lower hemisphere) obtained from X-ray texture goniometry and crystal-fabric analyser. Colour bar charts indicate multiples of uniform distribution (equals to 1.0) of CPO. The reference frame and the geographic coordinates are indicated on the top. Pole figures view towards the west on projection plane and refer as reference frame to the foliation pole $(\mathrm{Z})$ and object lineation $(\mathrm{X})$. 
Wn, was estimated through the Wallis (1995) method for the orientation of oblique grain shape fabrics.

Quartz and dolomite textures, i.e. crystallographic preferred orientation (CPO), on ten samples (Tab. 1) were measured at the "Geoscience Centre of the University of Göttingen”, Germany, with an X-ray Texture Goniometer (model X'Pert Pro MRD_DY2139 by PANalytical). A $2 \Theta$ standard diffraction pattern of $5-75^{\circ}$ has been measured to ensure the mineral phases composition for each sample. Spot analyses (6 spots of c. $7 \mathrm{~mm}$ in diameter) were performed on rock slides of c. $5 \times 3 \mathrm{~cm}^{2}$ approximating the $\mathrm{XZ}$ and $\mathrm{YZ}$ (section normal to the mineral lineation and foliation) planes. Pole figures (equal area lower hemisphere projection) were recalculated for the most relevant crystallographic planes and directions of quartz and dolomite by the orientation distribution functions (ODFs) through Mtex Toolbox (v. 5.4.0, https:// mtex-toolbox.github.io) of Matlab software. For quartz, $\mathrm{a}=\mathrm{b}=4.913 \AA, \mathrm{c}=5.405 \AA$ (point group ' 312 ') were adopted; for dolomite $\mathrm{a}=\mathrm{b}=4.801 \AA, \mathrm{c}=16.002 \AA$ (point group ' 312 '). ODFs were calculated through the radially symmetric de la Vallee Poussin kernel function (Schaeben, 1997), with a halfwidth of $10^{\circ}$ to attenuate artifacts. Quartz and dolomite CPO intensity were calculated through the texture index (or J-index) of Bunge (1982), specifically designed for large ODF dataset. For quartz $[c]$-axis patterns, when a cross girdle was recognized (e.g. Fig. 2e), the fabric openingangle was measured.

As in X-ray diffraction the outer part of the pole figure cannot be measured and is only recalculated from ODFs, a further independent quartz texture analysis was performed, as comparison, on standard thin sections (six quartz-bearing paragneisses and quartzites, Tab. 1). A G60+ automated crystal-fabric microanalyzer from Russell-Head Instruments was adopted at the Georg-August University of Göttingen, providing only the $[c]$-axis of quartz $(1000$ crystals for each sample). The Matlab-based FAME (C 2017 software (https://peternell.org/archive.html by Hammes and Peternell) was used. When quartz and second-phase minerals in a thin section couldn't be distinguished by FAME (C) 2017, the Investigator G50 software (v.5.12) allowed for a semi-automatically selection of those quartz crystals to be measured. Quartz fabric opening-angle was then recalculated through an independent Matlab script (available at: https://osf.io/ays5w/).

\section{RESULTS - STRUCTURAL ANALYSIS}

By integrating the geological map of Colchen et al. (1986) and the updated map of Parsons et al. (2016b) with original unpublished mapping from Carosi, Iaccarino, Montomoli, Simonetti, and Visonà during two field expeditions (2016 and 2017), a simplified geological map is provided in Fig. $1 \mathrm{~b}$.

At the mesoscale, the MCTz is described as a c. 10 km-thick top-to-the-south mylonitic shear zone (Fig. 1b, c), involving both LHS and GHS rocks (see also Fig. 2af). A pervasive mylonitic foliation, defined by biotite and white mica, strikes c. N70-80 ${ }^{\circ}$ and dips $20-45^{\circ}$ toward the N (Fig. 1b, c, see also Colchen et al., 1986). This fabric is related to shearing along the MCTz (Colchen et al., 1986; Searle et al., 2008 with references; Larson et al., 2010), commonly associated to the formation of a mylonitic foliation hereafter indicated as S2. North-trending mineral lineation (L2), defined by quartz rods and mineral shape preferred orientation, occur (see also Colchen et al., 1986; Larson et al., 2010; Parsons et al., 2016b). At the MCTz base, gneissic layering related to an older S1 foliation, is folded (Fig. 1b, see also Colchen et al., 1986; Larson et al., 2010), showing c. $20^{\circ}$ plunging axes (A2). Also, object lineation L2, including mineral lineation and stretching lineation (Piazolo and Passchier, 2002) occurs (Colchen et al., 1986; Larson et al., 2010; Parsons et al., 2016b).

From detailed sampling and careful microstructural observations, the MCTz I is placed between Besi Sahar (Marsyandi Valley) and Soti Khola (Budhi Gandaki valley), where S-C fabric, pointing a top-to-the-south sense of shear, occurs (Tab. 1). The LHS, here, encompasses greenschist facies quartzite in the garnet-zone (Kuncha Fm., samples MA16-01, MA16-03 and MA16-06), massive quartzites (Ghandrung quartzites, samples MA16-10 and MA16-11) and quartz-rich paragneiss, belonging to the staurolite-zone (sample MA16-14) (Tab. 1; e.g. in Fig. 2e-f) (Colchen et al., 1986; Larson \& Godin, 2009; Parsons et al., 2016b). Up-section, dolomite-bearing impure gneiss and dolomitic marbles within the kyanite-zone (sample MA1616, MA16-17, MA16-18, MA16-19, and MA16-20; lower and upper limestone/dolostone of Colchen et al., 1986) occur at the MCTz II in the Budhi Gandaki valley (Tab. 1; e.g. in Fig. 2a-c). In the Marsyandi valley amphibolite-facies massive quartzite and garnet-tourmaline-rich quartzite in the kyanite zone crop out at the MCTz II location (samples MA16-102, Fig. 2d, and MA16-101). These rocks correspond to the massive quartzites of the GHS of Parsons et al. (2016b) and to the "upper quartzites" of the LHS of Colchen et al. (1986).

At the microscale, S-C fabric (Fig. 2f), oblique foliation (Fig. 2b, c), snowball garnet, mineral (e.g. mica, plagioclase) fish and porphyroclasts with asymmetric strain shadows confirm the top-to-the-south sense of shear. At the MCTz $\mathrm{I}$, a relic of an older foliation, S1, occurs within the S2 microlithons. Evidences of S1 relicts fade towards higher structural levels (see also Larson et al., 2010).

In most samples along both studied valleys, granoblastic layers of quartz constitute the interconnected weak matrix, accounting over $20 \%$ in volume (Handy, 1994). At the MCTz I, quartz exhibits abundant subgrains and a slight bimodal grain sizes distribution, with minor grain size differences between smaller and coarser grains (e.g. sample MA16-06, Fig. 2f). Quartz is, therefore, interpreted to have recrystallized in both the subgrain rotation (SGR) and grain boundary migration (GBM) regimes (see Law, 2014 for general microstructures classification). In samples structurally higher, quartz lobate and interconnected grain boundaries, undulose extinction, and unimodal grain size distributions (e.g. micro-photos in Fig. 2e, f) are interpreted to be related to a GBM type I dynamic recrystallization regime (Law, 2014 with references). At the MCTz II, coarsegrained quartz crystals show overpinning microstructures, typical for GBM type II, and a loosely defined polygonal texture (MA16-102, MA16-101) pointing to a partial effect of static recrystallization or annealing or a drop in strain rate or grain boundary area reduction processes (e.g. Law, 2014).

In the upper and lower dolomitic marbles layers of the Budhi Gandaki valley (lower and upper limestone/ dolostone of Colchen et al., 1986), along the MCTz profile, 
dolomite is the strongly recrystallized matrix, accounting for over $75 \%$ of the bulk mineral volume (Fig. 2a-c). Rare twins in dolomite are recorded (Fig. 2c). Dolomite shape preferred orientation defines oblique foliations (Fig. 2b, c), coherent with a top-to-the-south shear sense, showing that dolomite deformation is related to the southward transport along the MCTz. Dolomite straight grain boundaries and unimodal grain size distribution support a deformation in the GBM regime with later dislocation-accommodated grain boundary sliding (Leiss \& Barber, 1999; Wells et al., 2019). Within two dolomitic marbles, at the MCTz II (samples MA16-17 and MA16-19), oblique foliations (Fig. 2b, c) define angles of $25^{\circ}$ and $22^{\circ}$, respectively, with a statistic uncertainty of c. $2^{\circ}$. Adopting the orientation of oblique grain shape fabrics method (Wallis, 1995), these angles correspond to sectional kinematic vorticity number, $\mathrm{Wn}=0.64-0.81$ (Fig. 3a).

\section{RESULTS - TEXTURE ANALYSIS}

Quartz CPOs has a medium-to-low intensity of 1.101.29 (J-index; Bunge, 1982), and a maximum strength recorded by the most homogeneous sample, MA16-102 ( $\mathrm{J}$-index $=2.91$ ), at the structural top. The different $\mathrm{J}$-indexes reflect the compositional and structural heterogeneity of the polymineralic samples within the MCTz, rather than a strain distribution. Indeed, interlayer micas and second-phase minerals (abundant in samples with lower CPO) attenuate/ prevent the CPO intensity (Tullis \& Wenk, 1994). However, a well-developed texture occurs in all samples (Fig. 2a'-f'). Compatible quartz textures are provided from both X-ray Texture Goniometry and the results obtained with the crystal-fabric microanalyzer (e.g. in Fig. 2d'-f').

(a)

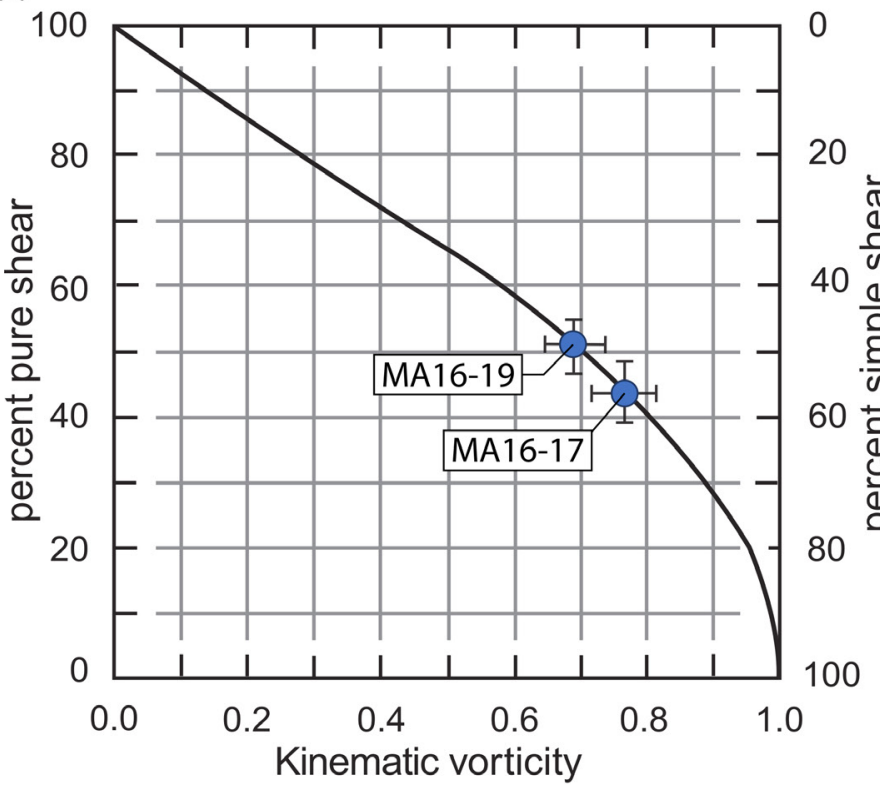

Most of quartz and dolomite textures show a sinistral asymmetry of the [c]-axis maxima (see [0001] pole figures in Fig. 2a'-f'). Comparing the sample's coordinate system with the geographical one, quartz and dolomite CPO asymmetries are synthetic to southward transport of the MCTz (Wallis, 1995; Leiss \& Barber, 1999).

A systematic variation of the texture patterns occurs throughout the MCTz vertical profile. From bottom to top, quartz $[c]$-axis distributions support point maxima in the Z-direction of the finite strain ellipsoid (e.g. sample MA16-06, Fig. 2f'), incomplete cross girdle Type I pattern (e.g. sample MA16-11, Fig. 2e') and point maxima in the Y-direction/single girdle pattern at the top (sample MA16102, Fig. 2d'). Adopting the empirical fabric opening-angle geothermometer of Faleiros et al. (2016) on quartz cross girdle patterns of three samples at the MCTz base (MA16-03, MA16-10; MA16-11), small opening angles (60-68 ${ }^{\circ}$ support deformation temperatures of c. $460-520 \pm 50^{\circ} \mathrm{C}$ (Fig. 3b).

Dolomite textures define well-developed, slightly asymmetric, $[c]$-axis single girdle patterns, with strong peripheral maxima close to the Z-direction (e.g. samples MA16-17, MA16-19, and MA16-20; Fig. 2a'-c'). At the MCTz top (sample MA16-20, Fig. 2a'), dolomite $<a>$-axes define strong maxima close to the X-direction (see $<110>$ pole figure). This pattern is interpreted to support intracrystalline $\{f\}$-slip/twinning deformation in dolomite (Barber et al., 1981). According to Barber et al. (1981), $\{f\}$ slip in dolomite develops at temperatures above $550-600^{\circ} \mathrm{C}$.

\section{DISCUSSIONS}

The MCTz definition and location are crucial points for a correct modelling of the Himalayan crystalline core exhumation. However, several methods have been used

(b)

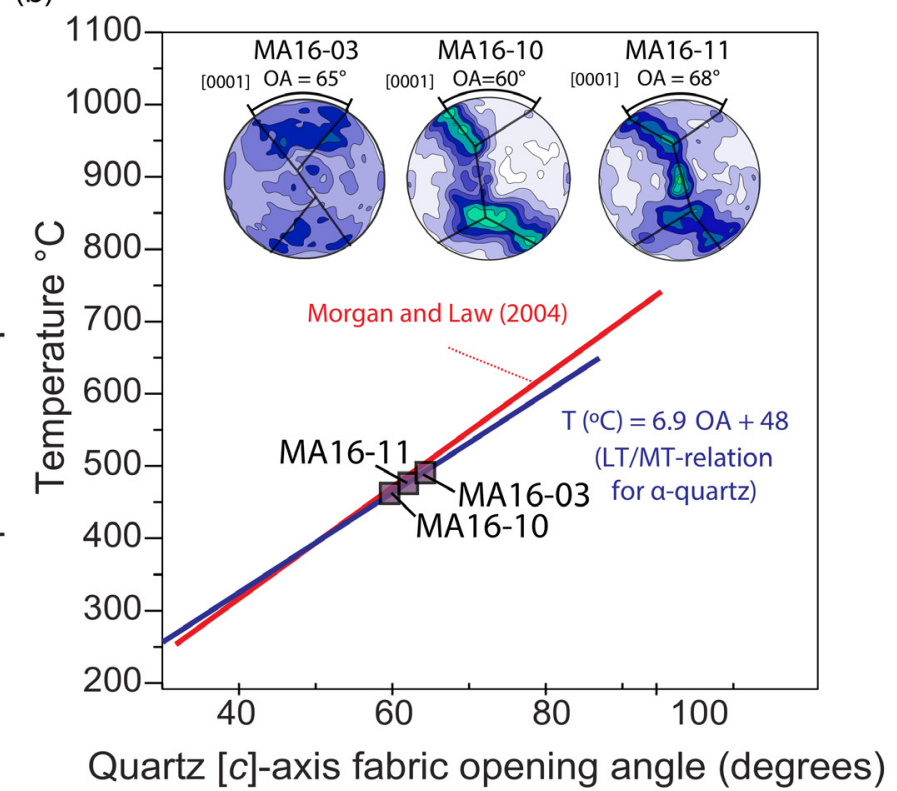

Fig. 3 - (a) Graph for kinematic vorticity estimates based on Law et al. (2004). The relationship between the kinematic vorticity and relative components of pure and simple shear is given for an instantaneous 2D flow. (b) Quartz [c]-axis fabric opening angle (OA) temperature diagram, with the linear fits of Morgan \& Law (2004) and Faleiros et al. (2016). Purple squares correspond to the quartz [c]-axis opening angles 
to define the MCTz limits, e.g. following a lithological contrast, a mineral-in isograd, age constrains or strain gradient (Searle et al., 2008). In the study area (Manaslu range, Western Nepal), the lower MCT limit (MCTz I) has been placed close to the garnet-zone (sample MA16-01, Fig. 1b), and the upper boundary (MCTz II) as coinciding with the Chomrong thrust (Colchen et al., 1986; Hodges et al., 1996). The localization of the lower limit, MCTz I, was chosen on the basis of microstructural (e.g. S-C fabric at the microscale, Fig. 2f) and texture evidences (asymmetric quartz CPO, e.g. Fig. 2f'). Furthermore, the localization of MCTz I at this structural level is compatible with the appearance of the garnet-in isograde, commonly attributed to the base of the MCTz (e.g. in the nearby Lower Dolpo region, Carosi et al., 2007).

Kinematic indicators, from the outcrop scale to the mineral texture-scale, support a south-directed flow, which is in general agreement with the southward extrusion of the $\mathrm{GHS}_{\mathrm{L}}$ through the MCTz. A general shear at the MCTz II is documented by dolomite grain shape oblique foliations, which provided $\mathrm{Wn}=0.64-0.81$. These values are based on the use of the mylonitic foliation as the reference frame for the shear plane, which is really unknown for the kilometre-thick shear zone. However, it is possible to assume that the mylonitic foliation tends to be parallel to the shear plane under high strain conditions (Fossen, 2016). High-strains are described for the MCTz (see also Searle et al., 2008 with references), and balanced crosssection and modelling of the MCTz in the Budhi Gandaki valley provided c. $116 \mathrm{~km}$ of shortening in almost $10 \mathrm{~km}$ of thickness (Khanal and Robinson, 2013). The MCTz is, therefore, a suitable case for using macroscopic mylonite foliation for approximating the shear plane.

Samples analysed for their kinematic vorticity belong to the structurally-higher section of the MCTz II. For a monocline plane strain deformation, the obtained kinematic vorticity data $(\mathrm{Wn}=0.64-0.81)$ support an important pure shear contribution of $40-56 \%$ (Fig. 3a). This compares with Larson et al. (2010) mean kinematic vorticity (Wm) estimates for the MCTz along the Budhi Gandaki and Daraudi valleys through the rigid grain net method. Particularly, Larson et al. (2010) found kinematic vorticity of $\mathrm{Wm}=0.50-0.73$, at the $\mathrm{MCTz}$ core, and $\mathrm{Wm}=0.72-0.87$ at the top of the $\mathrm{MCTz}$ (comparable to MA16-19 sample structural level, Fig. 2).

These values are in line with available data for the MCTz along the Himalaya, from west-to-east. In NW India, Kanyan et al. (2021) provided through the rigid grain net method $\mathrm{Wm}=0.60-0.88$ (from top to bottom of the MCTz), which overlap with Law et al. (2013) estimates of $\mathrm{Wm}=0.75$ 0.82 combining the rigid-grain orientation method and the oblique recrystallized grain/quartz [c]-axis fabric of Wallis (1995). In Western Nepal, Carosi et al. (2007) provided $\mathrm{Wm}=0.66-0.77$, through the stable porphyroclasts method, that compares with Larson \& Godin (2009) estimates (rigid grain net method) of $\mathrm{Wm}=0.49-0.80$ closely westward to the Manaslu study area. Also, in Eastern Nepal estimates of $\mathrm{Wm}=0.63-0.77$ are proposed (Jessup et al., 2006).

The highest simple shear contributions have been estimated by Law et al. (2013) coupling the rigid-grain orientation method and the oblique recrystallized grain/ quartz $[c]$-axis fabric of Wallis (1995) for the immediate hanging wall to the MCTz in India. In this work, kinematic vorticity values of $\mathrm{Wm}=0.90-0.95$ are associated to deformation temperatures of $510-610^{\circ} \mathrm{C}$ (Law et al., 2013). However, the majority of the data along the Himalaya supports a pure shear contribution for the MCTz, upto $\mathrm{Wm}=0.49-0.58$ for the structurally upper levels at the MCT base (rigid grain net method, see Montemagni et al., 2020). As recently suggested by Montemagni et al. (2020) and Kanyan et al. (2021), the kinematic vorticity and the simple shear component decrease toward the south along the MCTz profile. Linking with the southward migration of the MCTz toward upper-structural levels (e.g. Searle et al., 2008 with references), and with temporal constrains of 8-9 Ma (Vaikrita thrusts) to 5-4 Ma (Munsiari Thrust), Montemagni et al. (2020) showed that pure shear components increased during the last stage of deformation of the MCTz along its structurally shallower boundary (Munsiari Thrust). Therefore, the MCTz evolved from a simple shear dominated flow to a general shear flow, with large contributions of pure shear, according to the temporal "decelerating strain-path" of Grasemann et al. (1999).

The present estimates are in agreement with the southdirected flow of the $\mathrm{MCTz}$, documented along the belt. Therefore, dolomite asymmetric fabrics (both oblique foliation and asymmetric CPO) can be linked with the southward exhumation of the GHS along the MCTz II. Dolomite textures were interpreted to reflect deformation temperatures of $550-600^{\circ} \mathrm{C}$, in agreement with $\{f\}$ slip/ twinning in dolomite (Barber et al., 1981). Also, dolomite oblique foliations developed at that temperatures, recording the last deformation increment with vorticity of $\mathrm{Wn}=0.64-0.81$ at $550-600^{\circ} \mathrm{C}$. Therefore, dolomite oblique foliations developed at deformation temperature and kinematic conditions comparable to those proposed by Law et al. (2013) for the MCTz hanging wall. Thus, the present results for the MCTz are in line with the idea of relatively high kinematic vorticity records at high deformation temperatures and deeper structural levels, as predicted by the "decelerating strain-path" (Grasemann et al., 1999; Montemagni et al., 2020).

This consideration is valid if the same down-section temperature gradient and rejuvenation of the structure occur in the study area. Indeed, quartz and dolomite microstructures in the studied samples show vertical variations throughout the MCTz vertical profile (Fig. 2). A down-section transition from GBM type II regime quartz deformation mechanism, at the MCT II, to GBM type I down-to SGR/GBM regime occurs. Also, quartz textures show a transition from $[c]$-axis point-maxima in Y-direction/single girdle patterns (sample, Fig. 2d') at the top, to Z-point maxima pattern (sample, Fig. $2 \mathrm{f}^{\prime}$ ). The downsection transitions described for quartz microstructures and textures typically correspond to (i) increase in strain rates from the MCTz II to the MCTz I or (ii) decrease of deformation temperatures. There are not constraints on the strain rates for the study samples; however, a downsection deformation temperature decrease is documented by the metamorphic mineral assemblage (e.g. Carosi et al., 2007; Iaccarino et al., 2017). Amphibolite facies rocks in the kyanite-zone in the MCTz II gradually pass downsection to rocks in the staurolite-zone and in the garnetzone at the MCTz I.

Texture analyses obtained by the crystal-fabric microanalyzer allowed us to obtain the quartz [c]-axes distribution of the outer part of the pole figure (on [0001] pole figures). It allowed us to identify cross-girdle patterns, 
used for the quartz fabric opening-angle geothermometer of Faleiros et al. (2016). Therefore, a down-section temperature decrease is documented comparing the dolomite textures from X-ray texture goniometry $(>550$ $600^{\circ} \mathrm{C}$ ) at the top, and the quartz fabric opening-angle for samples at the MCTz base $\left(460-520 \pm 50^{\circ} \mathrm{C}\right)$. These estimates fit with the MCTz temperature gradient proposed for several study areas along the Himalaya, and particularly with the temperature range from $650-700^{\circ} \mathrm{C}$ down to 450 $400^{\circ} \mathrm{C}$ proposed for Western Nepal (e.g. Carosi et al., 2007; Larson et al., 2010; Parsons et al., 2016a; Iaccarino et al., 2017). Therefore, these results support the same downsection decrease of temperatures, which compares with the idea of the down-section "decelerating strain-path" model revisited by Montemagni et al. (2020).

\section{CONCLUSIONS}

- The MCTz has been investigated from the lower to the upper limit along two valleys around the Manaslu area of Western Nepal.

- Combining microstructural analysis and two different methods for texture analysis (X-ray Texture goniometry and crystal-fabric microanalyzer), a south-directed ductile non-coaxial deformation, linked to the MCT flow, is recognized and characterized. Coupling with metamorphic index-minerals and already published data, a down-section deformation temperature decrease occurs.

- Kinematic vorticity estimates based on HT-dolomite grain-shape oblique foliation support a general shear flow, with a significant pure shear component (40$56 \%$ ), recorded by mylonites formed at deep structural levels along the MCTz II. Compared with literature data, kinematic vorticity results are in line with the "decelerating strain-path" model.

- Combining X-ray texture goniometry and crystalfabric microanalyzer is a powerful strategy to ensure the characterization of quartz full-fabric with a good accuracy.

\section{ACKNOWLEDGMENTS}

I gratefully thank Prof. Chiara Montomoli, Dr. Salvatore Iaccarino, and Prof. Rodolfo Carosi for providing field data on sampling, for their support with the project conceptualization, and for in-depth constructive discussions. I also acknowledge the staff at the Department of Structural Geology and Geodynamics of the Georg-August-University of Göttingen, for the assistance during analyses. I am very grateful to Dr. Bernd Leiss for the critical discussions, especially on the applied techniques. Prof. S. Zanchetta and Dr. E. Fazio are warmly thanked for their reviews that improved the quality of the paper. The Associate Editor, G. Vignaroli, is thanked for the handling of the paper and for the useful comments. This research is part of a PhD program funded by the Tuscany Regional Pegaso doctoral grant.

\section{REFERENCES}

Barber D.J., Heard H.C. \& Wenk H.R. (1981) - Deformation of dolomite single crystals from $20-800^{\circ}$ C. Phys. Chem. Miner., 7 , 271-286.

Bunge H.J. (1982) - Texture analysis in materials science, 1st Edition: mathematical methods. Butterworth-Heinemann, London, 614 pp.

Carosi R., Montomoli C. \& Visonà D. (2007) - A structural transect in the Lower Dolpo: Insights on the tectonic evolution of Western Nepal. J. Asian Earth Sci., 29, 407-423.
Colchen M., Le Fort P. \& Pêcher A. (1986) - Recherches geologiques dans l'Himalaya du Nepal: Annapurna-Manaslu-Ganesh Himal; notice de la carte géologique au 1/200 000e; edition bilingue français-anglais. Ed. du C.N.R.S., Paris.

Faleiros F.M., Moraes R.D., Pavan M. \& Campanha G.D.C. (2016) A new empirical calibration of the quartz c-axis fabric openingangle deformation thermometer. Tectonophysics, 671, 173-182.

Fazio E., Punturo R., Cirrincione R., Kern H., Pezzino A., Wenk H.R., Goswami S. \& Mamtani M.A. (2017) - Quartz preferred orientation in naturally deformed mylonitic rocks (Montalto shear zone-Italy): a comparison of results by different techniques, their advantages and limitations. Int. J. Earth Sci., 106, 2259-2278.

Fossen H. (2016) - Structural geology. Cambridge University Press, New York, 510 pp.

Godin L., Ahenda M., Grujic D., Stevenson R. \& Cottle J. (2021) Protolith affiliation and tectonometamorphic evolution of the Gurla Mandhata core complex, NW Nepal Himalaya. Geosphere, 17, https://doi.org/10.1130/GES02326.1.

Grasemann B., Fritz H. \& Vannay J.C. (1999) - Quantitative kinematic flow analysis from the Main Central Thrust Zone (NW-Himalaya, India): implications for a decelerating strain path and the extrusion of orogenic wedges. J. Struct. Geol., 21, 837-853.

Handy M.R. (1994) - Flow laws for rocks containing two non-linear viscous phases: a phenomenological approach. J. Struct. Geol., 16, 287-301.

Hodges K.V., Parrish R.R. \& Searle M.P. (1996) - Tectonic evolution of the central Annapurna range, Nepalese Himalayas. Tectonics, $15,1264-1291$.

Iaccarino S., Montomoli C., Carosi R., Massonne H.J. \& Visonà D. (2017) - Geology and tectono-metamorphic evolution of the Himalayan metamorphic core: insights from the Mugu Karnali transect, Western Nepal (Central Himalaya). J. Metamorph. Geol., 35, 301-325.

Iaccarino S., Montomoli C., Montemagni C., Massonne H.J., Langone A., Jain A.K., Visonà D. \& Carosi R. (2020) - The Main Central Thrust zone along the Alaknanda and Dhauli Ganga valleys (Garhwal Himalaya, NW India): Insights into an inverted metamorphic sequence. Lithos, 372, 105669, https://doi org/10.1016/j.lithos.2020.105669.

Jessup M.J., Law R.D., Searle M.P. \& Hubbard M.S. (2006) - Structural evolution and vorticity of flow during extrusion and exhumation of the Greater Himalayan Slab, Mount Everest Massif, Tibet/ Nepal: implications for orogen-scale flow partitioning. Geol. Soc. Spec. Publ., 268, 379-413.

Kanyan L., Jain A.K. \& Singh S. (2021) - Vorticity patterns along the Main Central Thrust Zone, Alaknanda-Dhauli Ganga Valleys (Garhwal), Uttarakhand Himalaya. J. Earth Syst. Sci., 130, 1-21.

Khanal S. \& Robinson D.M. (2013) - Upper crustal shortening and forward modeling of the Himalayan thrust belt along the Budhi-Gandaki River, central Nepal. Int. J. Earth Sci., 102, 1871-1891.

Larson K.P. \& Godin L. (2009) - Kinematics of the Greater Himalayan sequence, Dhaulagiri Himal: implications for the structural framework of central Nepal. J. Geol. Soc., 166, 25-43.

Larson K.P., Godin L. \& Price R.A. (2010) - Relationships between displacement and distortion in orogens: Linking the Himalayan foreland and hinterland in central Nepal. Geol. Soc. Am. Bull., $122,1116-1134$.

Law R.D. (2014) - Deformation thermometry based on quartz c-axis fabrics and recrystallization microstructures: A review. J. Struct. Geol., 66, 129-161.

Law R.D., Stahr III D.W., Francsis M.K., Ashley K.T., Grasemann B. \& Ahmad T. (2013) - Deformation temperatures and flow vorticities near the base of the Greater Himalayan Series, Sutlej Valley and Shimla Klippe, NW India. J. Struct. Geol., 54, 21-53.

Leiss B. \& Barber D.J. (1999) - Mechanisms of dynamic recrystallization in naturally deformed dolomite inferred from EBSP analyses. Tectonophysics, 303, 51-69.

Montemagni C., Carosi R., Fusi N., Iaccarino S., Montomoli C., Villa I.M. \& Zanchetta S. (2020) - Three-dimensional vorticity and time-constrained evolution of the Main Central Thrust zone, Garhwal Himalaya (NW India). Terra Nova, 32, 215-224.

Parsons A.J., Hosseini K., Palin R. \& Sigloch K. (2020) - Geological, geophysical and plate kinematic constraints for models of the India-Asia collision and the post-Triassic central Tethys 
oceans. Earth-Sci. Rev., 208, 103084, https://doi.org/10.1016/j. earscirev.2020.103084.

Parsons A.J., Law R.D., Lloyd G.E., Phillips R.J. \& Searle M.P. (2016a) - Thermo-kinematic evolution of the Annapurna-Dhaulagir Himalaya, central Nepal: The Composite Orogenic System. Geochemistry, Geophys., Geosystems, 17, 1511-1539.

Parsons A.J., Law R.D., Searle M.P., Phillips R.J. \& Lloyd G.E. (2016b) - Geology of the Dhaulagiri-Annapurna-Manaslu Himalaya Western Region, Nepal. 1: 200,000. Journal of Maps, 12 https:// doi.org/10.1080/17445647.2014.984784.

Piazolo S., \& Passchier C.W. (2002) - Controls on lineation development in low to medium grade shear zones: a study from the Cap de Creus peninsula, NE Spain. J. Struct. Geol., 24, 25-44.
Schaeben H. (1997) - A simple standard orientation density function: The hyperspherical de la Vallée Poussin kernel. Phys. Status Solidi B, 200, 367-376.

Searle M.P., Law R.D., Godin L., Larson K.P., Streule M.J., Cottle J.M. \& Jessup M.J. (2008) - Defining the Himalayan main central thrust in Nepal. J. Geol. Soc., 165, 523-534.

Wallis S. (1995) - Vorticity analysis and recognition of ductile extension in the Sanbagawa belt, SW Japan. J. Struct. Geol., 17, 1077-1093.

Wells R.K., Holyoke III C.W., Newman J. \& Kronenberg A. (2019) Lattice-preferred orientation development in experimental and natural fine-grained dolomite shear zones. J. Struct. Geol., 128 103874, https://doi.org/10.1016/j.jsg.2019.103874. 